\title{
THE EFFECT OF THE GLOBAL FINANCIAL CRISIS ON THE MARKET STRUCTURE: THE CASE OF THE TURKISH BANKING SECTOR*
}

\author{
Küresel Finans Krizi’nin Türk Bankacılık Sektörü Piyasa Yapısı Üzerine Etkisi
}

\section{Mustafa ILDIRAR $^{* * *} \&$ İbrahim BAŞARAN ${ }^{* * * *}$}

Keywords:

Market Structure,

Competition,

Panzar - Rosse Model, Dynamic Panel Data,

Turksih Banking

Sector

JEL Codes:

D40, G21, L1.

\begin{abstract}
In this study, the market structure and competition level of the Turkish banking sector are investigated by employing a dynamic panel data method and using the data of the 2003-2018 period. For this purpose, within the framework of the non-structural Panzar-Rosse model, $\mathrm{H}$ statistical values were calculated for the period 2003-2018 and sub-periods 2003-2009 and 20102018 to investigate the effects of the Global Financial Crisis. According to the findings, the Turkish banking sector has a monopolistic competitive structure in the period of 2003-2018, in accordance with the classification in the literature. However, considering the structure of the Turkish banking sector, it can be stated that the sector has an oligopolistic structure. $\mathrm{H}$ statistical values also calculated for the 2003-2009 and 2010-2018 sub-periods that the level of competition in the sector is notably low, although the oligopolistic structure is maintained. Also, it is observed that the competition level of the sector decreased after the Global Financial Crisis, when the $\mathrm{H}$ statistics calculated for the two sub-periods are compared.
\end{abstract}

\section{$\ddot{O} z$}

$\mathrm{Bu}$ çalışmada Türk bankacılık sektörünün piyasa yapısı ve rekabet düzeyi, 2003-2018 verileri kullanılarak dinamik panel veri yöntemiyle araştırılmaktadır. Bu amaçla yapısal olmayan Panzar-Rosse modeli çerçevesinde önce 2003-2018 dönemi için, daha sonra Küresel Finans Krizinin etkilerini görebilmek amaciyla 2003-2009 ve 2010-2018 alt dönemleri için rekabet derecesini gösteren $\mathrm{H}$ istatistik değerleri hesaplanmıştır. Elde edilen bulgular Türk bankacılık sektörünün 2003-2018 döneminde, literatürde yer alan tasnife uygun olarak monopolcü rekabet yapısına sahip olduğu söylenebilirse de, sektörün oligopolistik bir yapıda olduğu rahatlıkla ifade edilebilir. 2003-2009 ve 2010-2018 alt dönemleri itibariyle hesaplanan H istatistik değerleri ise sektörün oligopol piyasa yapısını korumakla beraber ilgili dönemlerde rekabet düzeyinin ciddi derecede düşük olduğunu ortaya koymaktadır. Ayrıca iki alt dönem için hesaplanan $\mathrm{H}$ istatistik değeri karşılaştırıldığında, Küresel Finans Krizi sonrasında sektörün rekabet düzeyinin azaldı̆̆ı gözlenmiştir.

\footnotetext{
* This study was produced from master's thesis titled "Market Structure and Concentration: An Application on Turkish Banking Sector"

** Asst. Prof., Çukurova University, Faculty of Economics and Administrative Sciences, Department of Economics, mildirar@cu.edu.tr, ORCID: 0000-0001-6945-3364

*** Corresponding Author, Res. Asst., Turkish - German University, Faculty of Economics and Administrative Sciences, Department of Economics, ibrahim.basaran@tau.edu.tr, ORCID: 0000-00033211-0223
}

Makale Geliş Tarihi (Received Date): 23.02.2021 Makale Kabul Tarihi (Accepted Date): 14.04.2021 
M. Ildırar \& İ. Başaran, "The Effect of The Global Financial Crisis on the Market Structure: The Case of The Turkish Banking Sector"

\section{Introduction}

The financial sector, which provides the resources needed by the real sector for a sustainable growth and development aim, is of vital importance for all economies. The banking sector, which has the largest share in the financial system, performs important intermediation functions in terms of optimal resource allocation. To fulfill this function effectively, the competitive structure of the market in which they operate is critical and the banking sector's financial structure. Because the competitive structure of the sector can play a decisive role in directing resources to the most efficient investments. In other words, the function of banks to ensure optimal resource allocation depends on both their individual profitability and efficiency and the market structure in which they operate. On the other hand, as the competition level of the markets increases, the profits rate decrease and the prosperity of all economic units increases. Thus, markets with high competition are considered as the closest markets to optimal resource allocation. Considering the banking sector's role in economic policies, it can be said that the sector has a critical position in terms of can affect the entire economy. Therefore, determining whether the banking system has a competitive and efficient structure is an important research subject both theoretically and politically.

The concept of competition in terms of the Turkish banking sector came to the agenda with the Decisions of January 24, 1980 and it was aimed to strengthen the competitive structure of the sector with the financial liberalization policies implemented in the following years. However, the structure of the Turkish banking sector has displayed a very sensitive structure against macroeconomic facts and events, displaying a fluctuating performance against the crises experienced. Based on this, determining the competitive structure of the Turkish banking sector and analyzing how the economic events affected this structure make the subject important.

This study has two important aims. The first is to determine the competitive structure of the Turkish banking sector in general, and the second is to reveal how the 2008 Global Financial Crisis affected the competitive structure of the sector. In the study, the data of the Turkish Banking sector for the period of 2003-2018 were analyzed using the dynamic panel data method that includes the lagged values of the variables. The fact that this method has been adopted constitutes the main difference of the study. As is known, most economic relations have a dynamic structure and lagged values of variables such as economic growth and interest revenue can affect current period situations. Another difference of the study is a relatively recent period (2003-2018) was covered. The important aspect of analyzing this period is that it enables the determination of the impact of the Global Financial Crisis on the competitive structure of the banking sector. It is thought that the study will make a significant contribution to the relevant empirical literature, especially since the method adopted has not been used previously in the relevant literature.

The following section briefly reviews theoretical model and empirical literature. In the third section, the data set, econometric method and findings are explained. In section four presents the conclusions. 


\section{Theoretical Model and Empirical Literature}

\subsection{Theoretical Model}

Many methods have been developed to measure the competitive structure of a market in the literature. These methods are generally divided into two major groups as structural and nonstructural approaches. In the structural approaches developed within the framework of the Structure-Conduct-Performance (SCP) paradigm, variables such as the number of companies in the market and their market shares are considered. Examples of the criteria developed in this framework include N-firm Concentration Index, Herfindahl-Hirschman Index, Rosenbulth and Hall-Tideman Index, Hannah-Kay Index, U Index and Entropy Index. In short, the SCP paradigm assumes a relation between market structure and firm profitability/performance. Accordingly, there is a negative relationship between the level of market concentration and competition, and a positive relationship between the profitability of the firm. On the other hand, non-structural approaches were developed within the context of the New Empirical Industrial Organization paradigm (NEIO), which rejects this relation and emphasizes that there can also be competition in markets with high concentration levels. Non-structural approaches provide an idea about the market structure by using income, price and cost variables of firms (Bikker and Haaf, 2002a, p. 18). In our study, the Panzar - Rosse model, one of the non-structural competitive criteria, was used.

Panzar-Rosse (P-R) model was developed by John C. Panzar and James N. Rosse (1987) and has been used frequently in banking studies since the 1990s. The model developed for the American daily newspaper market assumes that both the amount of production and the revenues of the firm will decrease when the marginal cost of the firm increases, and it is applied to all markets (Panzar and Rosse, 1987, p. 443-456).

The P-R model is derived from the equilibrium condition of the monopolist firm and the profit maximization condition is shown by the following equation ${ }^{1}$ :

$$
R_{i}^{\prime}\left(x_{i}, n, z_{i}\right)-C_{i}^{\prime}\left(x_{i}, w_{i}, t_{i}\right)=0
$$

where $R_{i}, C_{i}, x_{i}, w_{i}, z_{i}, t_{i}$ and $n$ represent firm's revenues $(R)$, costs $(C)$ and output quantities (x), input prices (w), external factors which affecting firm's revenues and costs (z), and number of firms (n), respectively. Market equilibrium is as follows and $*$ sign denotes equilibrium values:

$$
R_{i}^{*}\left(x^{*}, n^{*}, z\right)-C_{i}^{\prime}\left(x^{*}, w, t\right)=0
$$

In the P-R methodology, the reduced form revenue function is first estimated for each firm, and then the sum of the elasticities of the reduced from revenues with respect to factor prices is calculated. This sum, called the $\mathrm{H}$ statistics, is used as a measure of competition.

Let $\partial R_{i}^{*} / \partial w_{K i}$ denote the derivative of total revenue with respect to the price of the ith input. Then, the Panzar and Rosse H-statistics can be written as follows:

\footnotetext{
${ }^{1}$ See Panzar and Rosse (1987) and Vesela (1995) for the derivation of revenue and cost functions and $\mathrm{H}$ statistical values.
} 


$$
H=\sum_{k=1}^{m} \frac{\partial R_{i}^{*}}{\partial w_{K i}} \frac{w_{K i}}{R_{i}^{*}}
$$

The H statistics shows how much the firm's revenue increases when input costs increase by $\% 1$. Therefore, the H-statistic values will represent different market structures and the level of competition of the market. Undoubtedly, the $\mathrm{H}$ statistic value will be smaller than zero for a monopoly firm. Because for a monopolist firm that provides profit maximization condition, the marginal costs will also increase when input prices increase, and thus the market price will increase while the equilibrium output level decreases. However, the increase in the market price will be lower than the decrease in the level of equilibrium output. Thus, the increase in input prices will cause a decrease in the firm's equilibrium revenue level.

Table 1. H-Statistic Values and Market Structures

\begin{tabular}{cc}
\hline H-Statistic Value & Market Structure \\
\hline $\mathrm{H} \leq 0$ & Monopoly \\
$0<\mathrm{H}<1$ & Monopolistic Competition \\
$\mathrm{H}=1$ & Perfect Competition \\
\hline
\end{tabular}

Source: Vesela (1995)

Shaffer (2004) explains the process of the model for the perfectly competitive market as follows: The long-term equilibrium of a perfectly competitive firm is achieved at the minimum point of the short and long-run average cost curves where normal profit conditions prevail. On the other hand, cost functions are homogenous of degree one in input prices This implies that cost doubles when input prices double. In this case, perfectly competitive firms whose demand curve is perfectly elastic will start to make loss even if they are making excessive profits because they cannot affect the market price. Therefore, firms will begin to leave the market, which will shift the supply curve left, increasing price and reducing losses. At the end of the process, the production amount of each firm will be the same as the previous level (the level before input prices do not increase) and the total revenue of the firm will increase by the product prices. Finally, in the long-run equilibrium, the total revenue of the competitive firm will be equal to the increase in input prices. In the other words, the $\mathrm{H}$ statistic value is equal to one in the perfectly competitive markets.

In the monopolistic competition market, the $\mathrm{H}$ statistic value takes a value between zero and one. Accordingly, when input prices increase, the revenue of the monopolistic competition firm also increase. However, this increase is lower than the rate of increase in input prices. Because, in these markets where entry and exit are free, the rise in costs causes exit from the market over time, and thus the demand for the goods of other firms that can remain in the market increases. As a result, this increase in demand will allow firm's revenue to increase despite the increase in input prices. Hence, for monopolistic competition markets, the $\mathrm{H}$ statistic value takes a positive value between zero and one (Panzar and Rosse, 1987, p. 447-448).

In the P-R model applications, reduced form revenue equation is used. The reduced form equation used in empirical studies related to the banking sector is generally as follows:

$$
\operatorname{lnTR}=\alpha+\left(h_{1} \ln P_{L}+h_{2} \ln P_{K}+h_{3} \ln P_{F}\right)+\lambda \ln B S F+\beta \operatorname{lnOI}+u
$$


Where TR is total interest revenue; $\underline{\mathrm{P}}_{\mathrm{L}}$ is the unit price of labor proxied by the ratio of personnel expenses to the total number of employees; $\underline{P}_{\underline{K}}$ is the unit price of capital proxied by the ratio of physical capital expenditure and other expenses to fixed assets; $\underline{P}_{F}$ is the unit price of funds proxied by the ratio of interest expense to total deposits.

The other independent variables include bank-specific factors as control variables.

In the equation (4), $\mathrm{P}_{\mathrm{L}}, \mathrm{P}_{\mathrm{K}}$ and $\mathrm{P}_{\mathrm{F}}$ are the unit input prices of the bank and the $\mathrm{H}$ statistic value in the P-R model is the sum of the coefficients $\left(h_{1}, h_{2}\right.$, and $\left.h_{3}\right)$ of these variables. There are also studies in the literature in which the ratio of total revenues (interest and non-interest revenue) or total interest revenues to assets are used instead of total interest revenues. However, it has been criticized because the ratio of total interest income to assets represents the price of the products instead of the bank revenue. In empirical studies, variables other than those giving $\mathrm{H}$ statistics may vary depending on the researcher's preference. In addition, the use of nonproportional variables such as total deposits and total assets as independent variables may cause the model to give erroneous results.

P-R model is a simple, single equation and linear model without time constraints since it requires a small amount of data at bank level. In addition, since it is not as complex as other non-structural models (such as the Bresnahan (1982), Lau (1982) and Iwata (1974) models), it is widely used to measure the market structure and degree of competition of the banking sector (Shaffer, 2004, p. 298).

\subsection{Literature Review}

There are many studies that to measure competition in the banking sector using the Panzar - Rosse model in the literature. Some selected studies are summarized below.

The first application of the P-R methodology to banking sector was made by Shaffer (1982). In the study using the data of banks operating in New York, the H statistic value in the long-term equilibrium was calculated between 0.32 and 0.36. Accordingly, the New York banking market is neither monopoly nor perfectly competitive, it has monopolistic competitive market characteristics.

Nathan and Neave (1989) measured the competitiveness of the Canadian banking sector for the period 1982-1984. According to the findings of the study, the H-statistics values are 1.058, 0.680 and 0.729 , respectively. These values indicate that the Canadian banking system was in perfect competition in 1982 and in monopolistic competition market conditions in 1983 and 1984.

In the study conducted by Molyneux, Lloyd-Williams and Thornton (1994), the competitive structure of the German, British, French, Spanish and Italian banking sector was investigated for the period 1986-1989. As a result of the study, although it is relatively easy to enter the banking market in EU countries, they found that there was no change in the competitive behavior of banks in the relevant period. They have demonstrated that in other countries except Italy, banks operate under monopolistic competition conditions, while in Italy they display monopolistic or oligopolistic behavior in the short run. 
Vesala (1995) examined the level of competition of the Finnish banking system for the period 1985-1992. In the study, it was determined that the Finnish banking system had perfect competition in 1989 and 1990 and a monopolistic competition structure in other years.

Bikker and Groeneveld (1998) investigated the competition level of the EU banking system based on 892 bank data of 15 EU countries between 1989-1996. The authors found that the EU banking sector has a monopolistic competitive market structure.

Bikker and Haaf (2002b) used the P-R model to measure the degree of competition in the banking systems of 23 countries, including European countries, and banks were analyzed in small, medium and large scale according to their size. According to the findings, banks in EU countries generally continued their activities in a monopolistic competitive market structure in 1991. It has been determined that the banking sectors of Austria, Belgium and Luxembourg are close to the perfectly competitive market. Considering the bank sizes, the average H-statistic value of 23 countries included in the sample was found to be higher for large banks. Accordingly, the average $\mathrm{H}$-statistic value of small banks was 0.64 , while this ratio was 0.86 for large banks.

Claessens and Laeven (2003) analyzed the banking sector of 50 countries, including Turkey, for the period 1994-2001. They found that the banking systems in the countries studied were generally closer to the monopolistic competitive market structure except 2-3 countries. According to the study, the Turkish banking system operated under monopolistic competition conditions in the period 1994-2001.

Świtała, Olszak and Kowalska (2013) aimed to determine the competitive structure of the Polish banking system using data from 53 commercial banks for the period 2008-2012. In the study using panel data, two different estimation methods were followed: Fixed effectsgeneralized least squares and generalized moments estimaton. According to findings the Polish banking system has a monopolistic competitive market structure in the whole period, although the average $\mathrm{H}$ statistical value obtained as a result of three different models shows a fluctuating structure.

Mustafa and Toçi (2017) examined the banking market competition conditions of 17 countries in Central and Eastern Europe (CEE) in the period 1999-2009. According to the $\mathrm{H}$ statistics value obtained from the dynamic panel data analysis using 300 bank data, it was found that CEE banks exhibit monopoly behavior. In addition, as a result of the study, it was determined that banks in EU member countries operate under more competitive conditions.

There are also studies in the literature to determine the competitive structure of the Turkish banking system. Some selected studies are summarized below.

Kasman (2001) is one of the first studies to apply the P-R model to the Turkish banking system. As a result of the study, which he examined the 1983-1996 period, it was found that commercial banks were monopolistic or oligopolistic in the short term in 1983, whereas they operated under monopolistic competition market conditions in the 1988-1996 period. The author attributes this development in the level of competition to the increase in the number of banks due to the gradual removal of market entry restrictions in the post-1980 period and especially the entry of foreign banks into the market. 
The H statistic value obtained in the study conducted by Günalp and Çelik (2006) using the 1990-2000 period data of 34 banks revealed that the Turkish banking sector has a monopolistic competitive market structure.

Abbasoglu, Aysan and Güneş (2007) examined the relations of concentration, competition, productivity and profitability in the Turkish banking sector for the 2001-2005 period. Two different models are used in the study, in which the ratio of interest income to total assets is used as the dependent variable. In both models, the $\mathrm{H}$ statistics took values ranging from 0.20 to 0.60 on average. Thus, in the post-crisis period, it has been demonstrated that the Turkish banking sector has a monopolistic competition feature.

Kocabay (2009) used both the P-R model and concentration ratios as a competition measurement methodology in his study, in which he analyzed the competition-stability dilemma in the Turkish banking sector. Fixed effects panel estimation method was used in the study where gross interest income was used as dependent variable. According to the findings, the $\mathrm{H}$ statistic value reaches its highest value of 0.80 in 1994 and then declines to its lowest value of 0.55 in 2000. According to the study, where the average of $\mathrm{H}$ statistics for the whole period is 0.61 , the Turkish banking system is in a monopolistic competitive market structure in the period of $1990-2008$.

Aktan and Masood (2010) calculated the H-statistic value as 0.753 for the 1998-2008 period in Turkish banking. According to the authors, it can be said that there is a monopolistic competition structure close to perfect competition market characteristics in the Turkish banking sector. The authors also examined how much and what factors affected the competitive level of the sector and divided these factors into two groups: market factors and bank-specific factors. In the study, while productivity, profitability and the ratio of equity to total assets are considered as market factors, concentration and foreign ownership are considered as banks-specific factors. In all models used in the study, it has been determined that efficiency affects competition negatively and profitability positively.

Macit (2012) analyzed the competition and concentration level of the Turkish banking sector in the period 2005-2010. The H statistical values for the 2005-2007 and 2008-2010 subperiods and the whole period were estimated by the author. In the study, the $\mathrm{H}$ statistic was estimated as 0.38 for the whole period and the competitive structure of the sector was similar for the sub-periods: while the period of 2005-2007 had a monopolistic competition feature, it was observed that the level of competition decreased in the 2008-2010 period and the market gained a monopolistic feature.

Karabay and Okay (2012) analyzed the competitive structure of the Turkish banking sector both in general and according to the ownership structure of banks in the period of 20022010. The $\mathrm{H}$ statistic value calculated using 31 commercial banks data was estimated as 0.61 for the whole sector and 0.52 for private deposit banks. The estimation made for foreign deposit banks showed a similar result, and it was determined that the sector has a monopolistic competitive market character. On the other hand, $\mathrm{H}$ statistics values calculated for foreign and private banks show that the competition between foreign banks is more intense.

Repková and Stavárek (2014) analyzed the competitive environment in the Turkish banking sector after the restructuring program. As a result of the econometric estimation using the P-R model, it was determined that the sector continued its activities under monopoly 
conditions in the period of 2002-2010. When the sub-periods of 2002-2006 and 2006-2010 are examined, it is seen that the sector is under monopoly competition and then monopoly conditions in the period following the restructuring process.

Celik and Citak (2016) discussed the competition in Turkish banking within the framework of economic growth in the post-financial liberalization period. In the study, while the $\mathrm{H}$ statistic value was found to be -0.22 for 1991 , it was estimated as 0.76 for 1992. The common finding reached in the context of $\mathrm{H}$ statistics values is that the sector showed a monopoly feature during the crisis years such as 1994, 2000-2002 and 2008-2009. On the other hand, sector activities continued in a monopoly environment in the last two years of the 1990-2014 period.

\section{Data, Empirical Method and Econometric Results}

\subsection{Data and Econometric Method}

After the 2000-2001 Crises, a serious restructuring period started in the Turkish banking sector and important structural changes occurred in the sector. The study examines how this restructuring process affects the competitive structure of the industry. In the study covering the period of 2003-3018, the study is divided into two sub-periods as 2003-2009 and 2010-2018 in order to examine the effects of the global financial crisis. Data were obtained from the Banks Association of Turkey website (www.tbb.org.tr).2 On the other hand, only deposit banks are covered in accordance with the P-R model.

Within the framework of the discussions in the literature (see, Bikker, Spierdijk and Finnie, 2006; De Bandt and Davis, 2000), only total interest revenue (TIR) was used as the dependent variable in the study and the reduced form income equation was determined as follows:

$$
\begin{gathered}
\log \text { TIR }_{t}=a_{0}+a_{1} \log P_{D_{t}}+a_{2} \log P_{K_{t}}+a_{3} \log P_{L t}+a_{4} \log E T A_{t}+a_{5} \log \operatorname{LOANAST}_{t}+ \\
a_{6} \log B B_{t}+u_{t}
\end{gathered}
$$

where $\mathrm{P}_{\mathrm{D}}, \mathrm{P}_{\mathrm{K}}$ and $\mathrm{P}_{\mathrm{L}}$ represent the unit cost of deposits (interest expenses / total deposits), the unit cost of capital (non-interest expenses / fixed assets), the unit cost of labor (staff expenses / total number of staff), respectively. The sum of the coefficients of these variables $\left(a_{1}+a_{2}+a_{3}\right)$ gives the $\mathrm{H}$ statistic value that shows the competitive level of the sector. ETA, LOANAST and $\mathrm{BB}$ are control variables that show the ratio of total equity to total assets, the ratio of total loans to total assets and the ratio of the number of bank branches to the total number of branches, respectively. ETA and LOANAST variables express the risks undertaken by banks, and BB variable represents the difference between bank sizes. According to Bikker et al. (2006), the $\mathrm{H}$ statistic value obtained by using the total asset variable as an independent variable in the model will show the upper market in terms of reflecting the interbank scale differences. Hence, the BB variable is used as the ratio of the number of bank branches to the total number of branches in this study.

Descriptive statistics of the variables are given in Table 2.

\footnotetext{
${ }^{2}$ Research and publication ethics were followed in this study. In addition, there is no need for ethics committee approval for this study.
} 
Table 2. Descriptive Statistics of Variables

\begin{tabular}{lccccc}
\hline Variables & Observation & Mean & Std. Dev. & Minimum & Maximum \\
\hline $\log$ TIR & 478 & 5.682319 & 1.006334 & 3.359266 & 7.549781 \\
$\log P D$ & 477 & -1.078991 & .4211855 & -2.724262 & 1.489908 \\
$\operatorname{logPL}$ & 486 & 1.895811 & .2678099 & 1.081923 & 2.643594 \\
$\log \mathrm{PK}$ & 478 & .1897502 & .4401043 & -1.227297 & 1.749447 \\
$\operatorname{logBB}$ & 495 & -2.291166 & 1.147808 & -4.048481 & -.0197368 \\
$\operatorname{logLOANAST}$ & 450 & -.4373379 & .4529534 & -2.855378 & -.072034 \\
$\operatorname{logETA}$ & 478 & -.8074473 & .2889519 & -1.405895 & -.0191176 \\
\hline
\end{tabular}

Source: Authors' Calculation

Panel data analysis, which includes both individual-specific fixed effects and time dimension, increases the degree of freedom and reduces the problem of multiple linear correlations. Also, parameter estimations are more reliable since there are many observations in panel data analysis, which also includes the unobservable heterogeneity and time effects. However, most of the economic relations are dynamic, and lagged values of variables such as economic growth affect their current situation. Thus, the lagged values of such variables may need to be included in the model. Besides, adding the lagged dependent variable to the model eliminates the problem of non-stationary residue in static panel data models (Greene, 2000). In our study, in which the competitive structure of the Turkish banking sector is estimated within the framework of Panzar-Rosse (1987) model, dynamic panel data model is used.

The dynamic panel data model is shown below (Blundell and Bond, 1998, p. 117-118):

$$
\begin{gathered}
y_{i t}=\alpha y_{i, t-1}+\beta x_{i t}+u_{i t} \\
u_{i t}=\mu_{i}+v_{i t}
\end{gathered}
$$

where $y_{i t}$ is the dependent variable (interest revenues), and $x_{i t}$ is the vector of explanatory variables (unit cost of funds, unit cost of capital, unit price of labour, total loans/total assets, total equity/total assets and number of bank branches / Total number of branches). Also, $\mathrm{E}\left(\mu_{i}\right)=\mathrm{E}\left(v_{i t}\right)=\mathrm{E}\left(\mu_{i} v_{i t}\right)=0$ for $\mathrm{i}=1, \ldots \ldots, \mathrm{N}$ and $\mathrm{t}=2, \ldots \ldots \mathrm{T}$ where $\mu_{i}$ and $v_{i t}$ denote the unobservable individual-specific fixed effects and time-varying disturbances, respectively. In other words, all the explanatory variables in the model are exogenous, and the error term has zero mean and constant variance.

If the lagged dependent variable and the error term are correlated, the inconsistent coefficient estimation results may arise in the fixed and random effect models. As a solution to this problem, the suggestion is to use the instrument variable instead of the lagged dependent variable (Cameron and Trivedi, 2005, p. 764; Greene, 2000).

In this context, Anderson and Hsiao (1981) suggested using $y_{i, t-2}$ as an instrumental variable instead of $\Delta y_{i, t-1}$ after taking the first difference of the model (equation 4). The instrumental variable estimation method proposed for the prediction of the dynamic panel model is consistent. But it is not efficient because it does not allow all moment conditions and does not consider the structure $\Delta u_{i t}$. According to Arellano and Bond (1991), this situation arises because all possible instrumental variables are not used. Therefore, they suggested using all lagged values of $y_{i t}$ and $x_{i t}$ as instrumental variables and thus developed the Generalized Method of Moments (GMM). However, first, Arellano and Bover (1995) and later Blundell and 
Bond (1998) built up a new approach called the system GMM (system dynamic panel data method), which combines the original and transformed equation into a single system. In this approach, the system-GMM estimator allows both the lagged levels of $y_{i t}$ in the first difference equations and the lagged differences of $y_{i t}$ in the level equations as an instrumental variable. Indeed, Blundell and Bond (1998) have shown that stationary restrictions that allow the use of a System-GMM estimator can add to the initial conditions (Baltagi, 2005, p. 147-148; Blundell and Bond, 1998).

The validity of the system-GMM estimator requires the implementation of three tests in the estimation process. The first is the Arellano-Bond autocorrelation test. Accordingly, there is a first-degree autocorrelation among the error terms. However, there should not be seconddegree autocorrelation in the model. The second is the Sargan test to check the validity of over identification constraints. If the test result is statistically significant, this indicates that the model is correctly defined, and the determined instrumental variables are appropriate. The last test is the Wald Chi-squared test which demonstrates whether the explanatory variables are significant in explaining the dependent variable together.

\subsection{Econometric Results and Discussion}

In the study, three different models were established in order to determine the competitive structure of the Turkish banking sector in the period of 2003-2018. The first model is estimated to examine the competitive structure of the sector throughout the period, and the second and third models to determine the competitive level of the sector before and after the Global Financial Crisis.

In each model, firstly, the diagnostic tests to control the validity of the System-GMM estimator were applied. In this context, Arellano-Bond autocorrelation test was performed for Model-1 first. At the end of the test, while there is first order autocorrelation in the model, no second order autocorrelation was detected as expected. Secondly, the validity of the instrument variables used in the model was tested with the Sargan Test and the statistics obtained showed that the instrument variables were appropriate at the 95\% confidence interval. Finally, the probability value of the Wald Test shows that the explanatory variables are significant together in explaining the dependent variable.

According to the estimation results of Model 1 summarized in Table 3, all explanatory variables are statistically significant. The sum of the coefficients giving the $\mathrm{H}$ statistic value was calculated as 0.23 . The sum of the coefficients giving the $\mathrm{H}$ statistic value was calculated as 0.23 . Therefore, it can be said that the Turkish banking sector had a monopolistic competitive structure in the 2003-2018 period. However, it is also possible to comment that the sector is closer to the oligopoly market due to the relatively small $\mathrm{H}$ statistic value. As a matter of fact, it can be stated that large banks in the sector are determinant in decisions such as pricing policy, and competition is more common among them. 
Table 3. Model - 1 Estimation Results (2003-2018)

\begin{tabular}{|c|c|c|c|c|c|c|}
\hline $\operatorname{logTIR}$ & Coefficients & Std. Err. & $Z$ & $P>Z$ & \multicolumn{2}{|c|}{ [\%95 Conf. Interval] } \\
\hline $\log$ TIR $(-1)$ & .9396444 & .0123056 & 76.36 & 0.000 & .9155258 & .9637629 \\
\hline $\log \mathrm{TIR}(-2)$ & -.0795318 & .0163353 & -4.87 & 0.000 & -.1115484 & -.047515 \\
\hline $\log P D$ & .0674052 & .0061509 & 10.96 & 0.000 & .0553496 & .0794607 \\
\hline $\log P K$ & -.1012264 & .0091218 & -11.10 & 0.000 & -.1191048 & -.083348 \\
\hline $\log P L$ & .272282 & .0156541 & 17.39 & 0.000 & .2416005 & .3029634 \\
\hline $\operatorname{logETA}$ & -.4671873 & .0181143 & -25.79 & 0.000 & -.5026906 & -.431684 \\
\hline logLOANAST & .073967 & .0124085 & 5.96 & 0.000 & .0496467 & .0982872 \\
\hline $\log B B$ & -.0274014 & .0110762 & -2.47 & 0.013 & -.0491103 & -.005692 \\
\hline \multicolumn{7}{|c|}{ Diagnostic Tests } \\
\hline \multirow{3}{*}{$\begin{array}{l}\text { Wald Test } \\
\text { Sargan Test } \\
\text { Arellano-Bond } \\
\text { AR Test }\end{array}$} & \multicolumn{6}{|c|}{$\chi^{2}(8)=6.30 e+06(0.0000)$} \\
\hline & \multicolumn{6}{|c|}{$\chi^{2}(46)=33.18081(0.9214)$} \\
\hline & \multicolumn{3}{|c|}{$A R(1)=-2.7996(0.0051)$} & \multicolumn{3}{|c|}{$A R(2)=-1.095(0.2735)$} \\
\hline
\end{tabular}

Source: Authors' Calculation

While Model 1 shows similar results in general with Macit (2012), Repková and Stavárek (2014) and Celik and Citak (2016), it differs from the study of Karabay and Okay (2012). In addition, Celik and Citak (2016) and Repková and Stavárek (2014) comment that monopolistic competition conditions prevail in the sector. However, it seems more appropriate to say that the Turkish banking sector has an oligopoly market structure. Because the $\mathrm{H}$ statistics are close to zero.

On the other hand, it is noteworthy that ETA and LOANAST, which are used as control variables, have an expected effect on total interest income, whereas BB variable does not have the expected effect. According to this, the increase in ETA and LOANAST rates decreases the interest income as expected. However, the increase in the BB rate has a decreasing effect on interest income contrary to expectations.

The aim of Model 2 is to determine the competitive conditions of the Turkish banking sector after the restructuring process and before the Global Financial Crisis. Before evaluating the findings, the Arellano-Bond autocorrelation test was performed first. At the end of the test, while there is first order autocorrelation in the model, no second order autocorrelation was detected as expected. The validity of the instrument variables used in the model was tested with the Sargan test and the statistics obtained showed that the instrument variables were appropriate at the $95 \%$ confidence interval. Finally, the probability value of the Wald test shows that the explanatory variables are significant together in explaining the dependent variable. In addition, all of the explanatory variables used in the model were found to be statistically significant. 
M. Ildırar \& İ. Başaran, "The Effect of The Global Financial Crisis on the Market Structure: The Case of The Turkish Banking Sector"

Table 4. Model - 2 Estimation Results (2003-2009 Sub-Period)

\begin{tabular}{|c|c|c|c|c|c|c|}
\hline $\log$ TIR & Coefficient & Std. Err & $Z$ & $\boldsymbol{P}>Z$ & \multicolumn{2}{|c|}{ [\%95 Conf. Interval] } \\
\hline $\log \mathrm{TIR}(-1)$ & .8421333 & .0307549 & 27.38 & 0.000 & .7818549 & .9024117 \\
\hline $\log P D$ & -.0609325 & .0193648 & -3.15 & 0.002 & -.0988868 & -.022978 \\
\hline $\log P K$ & -.1226789 & .0392057 & -3.13 & 0.002 & -.1995207 & -.045837 \\
\hline $\log P L$ & .519617 & .0737765 & 7.04 & 0.000 & .3750177 & .6642164 \\
\hline $\operatorname{logETA}$ & -.2505997 & .0691088 & -3.63 & 0.000 & -.3860504 & -.115149 \\
\hline logLOANAST & .0938156 & .0441257 & 2.13 & 0.033 & .0073308 & .1803005 \\
\hline $\log B B$ & .0549801 & .0293421 & 1.87 & 0.061 & -.0025294 & .1124896 \\
\hline \multicolumn{7}{|l|}{ Diagnostic Tests } \\
\hline \multirow{2}{*}{$\begin{array}{l}\text { Wald Test } \\
\text { Sargan Test } \\
\text { Arellano-Bond AR } \\
\text { Test }\end{array}$} & \multicolumn{6}{|c|}{$\begin{array}{c}\chi^{2}(7)=158992.11(0.0000) \\
\chi^{2}(12)=18.46185(0.1024)\end{array}$} \\
\hline & \multicolumn{3}{|c|}{$A R(1)=-2.8154(0.0049)$} & \multicolumn{3}{|c|}{$A R(2)=-.28165095(0.7782)$} \\
\hline
\end{tabular}

Source: Author's Calculation

Although the H statistic value for the 2003-2009 sub-period is higher (0.33) compared to the 2003-2018 period, it can be said that the oligopolistic competitive structure of the sector has not much changed. Considering the situation in the post-2001 crisis period, it can be said that the Turkish banking sector has neither a monopoly nor a monopolistic competitive market structure as a result of bank liquidations and mergers. On the other hand, it is seen that all explanatory variables in the model have the expected effect. In the 2003-2009 period, the ETA variable had a negative sign, while the LOANAST and BB variables positively affect the bank interest revenue.

The estimation results of Model-3 covering the 2010-2018 sub-period are summarized in Table 5. There are no problems with the diagnostic test results and all of the explanatory variables were statistically significant.

Table 5. Model - 3 Estimation Results (2010-2018 Period)

\begin{tabular}{|c|c|c|c|c|c|c|}
\hline $\log$ TIR & Coefficient & Std. Err. & $\boldsymbol{Z}$ & $\boldsymbol{P}>Z$ & \multicolumn{2}{|c|}{ [\%95 Conf. Interval] } \\
\hline $\log \mathrm{TIR}(-1)$ & .8509447 & .0033035 & 257.59 & 0.000 & .8444699 & .8574195 \\
\hline $\log P D$ & .0646768 & .0031186 & 20.74 & 0.000 & .0585643 & .0707892 \\
\hline $\log P K$ & -.1171395 & .0043933 & -26.66 & 0.000 & -.1257501 & -.108528 \\
\hline $\log P L$ & .2782756 & .0077141 & 36.07 & 0.000 & .2631563 & .293395 \\
\hline $\operatorname{logETA}$ & -.4808149 & .0051784 & -92.85 & 0.000 & -.4909644 & -.470663 \\
\hline logLOANAST & .1616834 & .0055723 & 29.02 & 0.000 & .1507618 & .1726049 \\
\hline $\log B B$ & -.048659 & .0033109 & -14.70 & 0.000 & -.0551482 & -.470663 \\
\hline \multicolumn{7}{|l|}{ Diagnostic Tests } \\
\hline \multirow{2}{*}{$\begin{array}{l}\text { Wald Test } \\
\text { Sargan Test } \\
\text { Arellano-Bond AR } \\
\text { Test }\end{array}$} & \multicolumn{6}{|c|}{$\begin{array}{c}\chi^{2}(7)=3.01 e+07(0.0000) \\
\chi^{2}(27)=32.5738(0.2115)\end{array}$} \\
\hline & \multicolumn{3}{|c|}{$A R(1)=-2.3828(0.0172)$} & \multicolumn{3}{|c|}{$A R(2)=-1.137(0.2555)$} \\
\hline
\end{tabular}

Source: Authors' Calculation

The $\mathrm{H}$ statistic value calculated from Model 3 shows that the competition level of the sector decreased in the period of 2010-2018 compared to the previous sub-period. While the $\mathrm{H}$ statistic value was 0.33 for the period 2003-2009, it was calculated as 0.22 for the period 20102018. In other words, the Global Financial Crisis has adversely affected the competitive structure of the banking sector. This situation can be explained by the emergence of similar 
tendencies in the Turkish banking sector as well as the banks' tendency to risk aversion as a result of bank liquidations, mergers and acquisitions in developed countries.

When the coefficients of the control variables are analyzed, it is seen that ETA and LOANAST variables have the expected effect on bank interest income, except for the BB variable. The negative impact of the $\mathrm{BB}$ variable on bank interest income can be explained by the fact that bank branches have gradually lost their importance as a result of rapid developments in mobile and internet banking in recent years, and banks consider increasing the number of branches as a cost increase. Another striking point here is that the coefficient of the ETA variable increases from -0.25 to -0.48 when compared to the two sub-periods. This increase can be explained by the increase in the capital adequacy ratio on average after the global financial crisis.

\section{Conclusion}

In this paper, the change in the level of competition of the Turkish banking sector was analyzed after the 2001 crisis. In the study in which the dynamic panel data method was applied within the framework of the non-structural Panzar-Rosse model, the data for the period of 20032018 were used. In addition, the sub-periods of 2003-2009 and 2010-2018 were analyzed in order to determine how the Global Financial Crisis affected the competitive structure of the sector.

According to the findings, the Turkish banking sector exhibits a monopolistic competitive market structure in the period of 2003-2018 (the H statistic for this period is 0.23). However, considering factors such as the market shares of the first 5 or 10 banks, high profitability rates, and the weight of public banks, it can be said that the competitive structure of the sector is closer to oligopoly. In addition, the existence of industry entry barriers such as capital constraints support this idea. When the sub-periods are examined, it is understood that the level of competition was higher in the 2003-2009 period compared to the general period, and decreased in the 2010-2018 period, although the sector preserved its oligopolistic market structure. As a matter of fact, while the H statistic value was 0.33 in the period of 2003-2009, this rate decreased to 0.22 after the Global Financial Crisis. This decrease in the level of competition can be attributed to increased regulations to restrict the risk-taking behavior of banks in the post-crisis period.

As a result of the findings of the study, it can be stated that it is especially accurate for private banks to take steps to become competitive with public banks. It would also be useful for policymakers to take steps from a holistic point of view, especially taking into account smallscale private banks with a large deposit base. In this context, it would be an appropriate study to conduct a competitive analysis on the basis of ownership and scale of the banks.

\section{Researchers' Contribution Rate Statement}

The authors declare that they have contributed equally to the article.

Declaration of Conflict of Interest

There are no potential conflicts of interest in this study. 
M. Ildırar \& İ. Başaran, "The Effect of The Global Financial Crisis on the Market Structure: The Case of The Turkish Banking Sector"

\section{References}

Abbasoglu, O. F., Aysan, A. F. and Gunes, A. (2007). Concentration, competition, efficiency and profitability of the Turkish banking sector in the post-crises period. Banks \& Bank Systems, 2(3), 106-115. Retrieved from https://core.ac.uk/

Aktan, B. and Masood, O. (2010). The state of competition of the Turkish banking industry: An application of the Panzar-Rosse model. Journal of Business Economics and Management, 11(1), 131-145. https://doi.org/10.3846/jbem.2010.07

Anderson, T. W. and Hsiao, C. (1981). Estimation of dynamic models with error components. Journal of the American Statistical Association, 76(375), 598-606. Retrieved from https://www.tandfonline.com/

Arellano, M. and Bond, S. (1991). Some tests of specificaiton for panel data: Monte Carlo evidence and an applicationto employment equations. The Review of Economic Studies, 58(2), 277-297. https://doi.org/10.2307/2297968

Arellano, M. and Bover, O. (1995). Another look at the instrumental variable estimation of errorcomponents models. Journal of Econometrics, 68(1), 29-51. https://doi.org/10.1016/03044076(94)01642-D

Baltagi, B. H. (2005). Econometric analysis for panel data (3rd Ed.). London: John Wiley and Sons.

Bikker, J. A. and Groeneveld, J. M. (1998). Competition and concentration in the EU banking industry. Retrieved from http://citeseerx.ist.psu.edu/viewdoc/download?doi=10.1.1.493.5081\&rep=rep1\& type $=$ pdf

Bikker, J. A. and Haaf, K. (2002a). Measures of competition and concentration in the banking industry: A review of the literature. Economic \& Financial Modelling, 9(2), 53-98. Retrieved from https://www.sid.ir/en/journal/

Bikker, J. A. and Haaf, K. (2002b). Competition, concentration and their relationship: An empirical analysis of the banking industry. Journal of Banking \& Finance, 26(11), 2191-2214. https://doi.org/10.1016/S0378-4266(02)00205-4

Bikker, J. A., Spierdijk, L. and Finnie, P. (2006). Misspecification of the Panzar-Rosse Model: Assessing competition in the banking industry (DNB Working Papers No. 114). Retrieved from http://citeseerx.ist.psu.edu/viewdoc/download?doi=10.1.1.474.8065\&rep=rep1\&type=pdf

Blundell, R. and Bond, S. (1998). Initial conditions and moment restrictions in dynamic panel data models. Journal of Econometrics, 87(1), 115-143. https://doi.org/10.1016/S0304-4076(98)00009-8

Bresnahan, T. F. (1982). The oligopoly solution concept is identified. Economics Letters, 10(1-2), 87-92. https://doi.org/10.1016/0165-1765(82)90121-5

Cameron, A. C. and Trivedi, P. K. (2005). Microeconometrics: methods and applications. UK: Cambridge University Press.

Celik, T. and Citak, L. (2016). Banking competition, financial liberalization and economic growth: Evidence from Turkish economy during the 19890-2014 period. International Journal of Economics and Financial Issues, 6(4), 1750-1755. Retrieved from https://www.econjournals.com/

Claessens, S. and Leven, L. (2003). What drives bank competition? Some international evidence. Journal of Money, Credit and Banking, 36(3), 563-583. Retrieved from https://www.jstor.org/

De Bandt, O. and Davis, E. P. (2000). Competition, contestability and market structure in European Banking sectors on the eve of EMU. Journal of Banking \& Finance, 24(6), 1045-1066. https://doi.org/10.1016/S0378-4266(99)00117-X

Greene, W. H. (2000). Econometric analysis. New Jersey: Prentice Hall.

Günalp, B. and Çelik, T. (2006). Competition in the Turkish banking industry. Applied Economics, 38(11), 1335-1342. https://doi.org/10.1080/00036840500405656

Iwata, G. (1974). Measurement of conjectural variation in oligopoly. Econometrica Journal of the Econometric Society, 42(5), 947-966. https://doi.org/10.2307/1913800 
Karabay, M. E. and Okay, P. (2012). An empirical study of the measurement of the level of competition in the Turkish banking system using Panzar - Rosse methodology. Rekabet Dergisi, 13(1), 3-49. Retrieved from https://www.rekabet.gov.tr/

Kasman, A. (2001). Competitive conditions in the Turkish banking industry. Ege Academic Review, 1(2), 72-82. Retrieved from https://core.ac.uk/

Kocabay, S. (2009). Bank competition and banking system stability: evidence from Turkey (Master Thesis). Retrieved from https://open.metu.edu.tr/bitstream/handle/11511/18927/index. pdf? sequence $=1$

Lau, L J. (1982). On identifying the degree of competitiveness from industry price and output data. Economic Letters, 10(1-2), 93-99. https://doi.org/10.1016/0165-1765(82)90122-7

Macit, F. (2012). Recent evidence on concentration and competition in Turkish banking sector. Theoretical and Applied Economics, 19(8), 19-28. Retrieved from http://www.ectap.ro/

Molyneux, P., Lloyd-Williams, D. M. and Thornton, J. (1994). Competitive conditions in European banking. Journal of Banking \& Finance, 18(3), 445-459. https://doi.org/10.1016/03784266(94)90003-5

Mustafa, A. and Toçi, V. (2017). Estimation of the banking sector competition in the CEE Countries: The Panzar-Rosse approach. Zbornik Radova Ekonomskog Fakulteta u Rijeci: Časopis za Ekonomsku Teoriju i Praksu, 35(2), 459-485. https://doi.org/10.18045/zbefri.2017.2.459

Nathan, A. and Neave, E. H. (1989). Competition and contestability in Canada's financial system: Empirical results. The Canadian Journal of Economics, 22(3), 576-594. https://doi.org/10.2307/135541

Panzar, J. C. and Rosse, J. N. (1987). Testing for "monopoly" equilibrium. The Journal of Industrial Economics, 35(4), 443-456. https://doi.org/10.2307/2098582

Repková, I. and Stavárek, D. (2014). Concentration and competition in the banking sector of Turkey. Amfiteatru Economic, 16(36), 625. Retrieved from https://www.amfiteatrueconomic.ro/

Shaffer, S. (1982). Nonstructural test for competition in financial markets. Federal Reserve Bank of Chicago, 225-243.

Shaffer, S. (2004). Patterns of competition in banking Journal of Economics and Business, 56(4), 287313. https://doi.org/10.1016/j.jeconbus.2003.10.003

Świtała, F., Olszak M. and Kowalska, I. (2013). Competition in commercial banks in Poland - analysis of Panzar-Rosse H-Statistics (UW Faculty of Management Working Paper Series 4). Retrieved from http://www.wz.uw.edu.pl/portaleFiles/5630-Faculty\%20of\%20M/WP/WPS42013SwitalaOlszak Kowalska.pdf

Türkiye Bankalar Birliği. (2019). 60. yılında Türkiye Bankalar Birliği ve Türkiye'de bankacılık sistemi 1958-2018. İstanbul: Türkiye Bankalar Birliği.

Vesala, J. (1995). Testing for competition in banking: Behavioral evidence from Finland. Helsinki: Bank of Finland Studies. 